prof. dr hab. inż. Janusz Mielniczuk

Politechnika Poznańska

Instytut Pojazdów Szynowych „Tabor”

dr inz. Marek Malinowski

Uniwersytet Zielonogórski

mgr inz. Pawel Kuligowski

Instytut Pojazdów Szynowych „Tabor”

\title{
Elementy powierzchniowe o strukturze porowatej w konstrukcji dachów pojazdów szynowych
}

\begin{abstract}
Na przykładzie konstrukcji dachu omówiono możliwości zastosowania w budowie pojazdów szynowych elementów powierzchniowych o strukturze porowatej. Przedstawiono zatożenia modelu takich elementów. Przeprowadzono analizę wytrzymałościowa fragmentu dachu z poszyciem o tradycyjnej konstrukcji stalowej i o strukturze porowatej oraz zestawiono porównanie wyników.
\end{abstract}

\section{Wprowadzenie}

Praca stanowi kontynuację wcześniej podjętych i opublikowanych badań [1].

Elementy konstrukcji dachów mogą być jednym z wielu możliwych obszarów zastosowań materiałów o strukturze porowatej $\mathrm{w}$ budowie taboru szynowego. Mogą one zastąpić tradycyjne konstrukcje stalowe.

W obecnie eksploatowanych pojazdach szynowych elementy dachowe posiadają najcześciej konstrukcję szkieletową, tzn. szkielet stalowy pokryty poszyciem w postaci blachy.

Przyjęcie elementów powierzchniowych o strukturze porowatej prowadzi do zmian termomechanicznych konstrukcji dachu.

W artykule porównano pod względem ugięciowym i naprężeniowym zachowanie się konstrukcji dachowych z poszyciem stalowym jednorodnym oraz o strukturze porowatej.

Obciążenia konstrukcji dachowych uzależnione są od funkcji jakie pełnią. Część z nich bowiem pełni rolę wyłącznie pokryw, podczas gdy inne mogą stanowić część konstrukcji nośnej pojazdu. W pierwszym przypadku o wytrzymałości decydują wyłącznie siły przykładane $\mathrm{z}$ zewnątrz, natomiast $\mathrm{w}$ drugim dodatkowo dochodzą obciążenia wewnętrzne pochodzące od współpracy z pozostałą częścią konstrukcji. W prezentowanej analizie rozpatrzono tylko pierwszy przypadek.

Obciążenie próbne dachów przewidziane w przepisach kolejowych (UIC, ERRI, normach europejskich itp.) ogranicza się jedynie do przyłożenia siły pochodzącej od poruszającego się po dachu człowieka (około $1 \mathrm{kN}$ ). Jednak niebagatelne znaczenie dla wytrzymałości konstrukcji dachu ma obciążenie pochodzące od zalegającego na nim podczas postoju śniegu. Z wstępnych obliczeń [2] wynika, że przy założeniu obciążenia jednostkowego równomiernie rozłożonego na poziomie $\mathrm{np}$. $\mathrm{q}=2 \mathrm{kN} / \mathrm{m}^{2}\left(\sim 200 \mathrm{kG} / \mathrm{m}^{2}\right)$, odkształcenia konstrukcji, zwłaszcza w kierunku pionowym, są zdecydowanie (nawet pięciokrotnie) większe niż od obciążenia człowiekiem. Wobec powyższego $\mathrm{w}$ analizie wytrzymałości dachu uwzględniono jedynie obciążenie pochodzące od śniegu.

\section{Numeryczna analiza ugięć i naprężeń}

Analizie poddano fragment konstrukcji dachu wagonu pasażerskiego składającego się $\mathrm{z}$ pięciu krokwi wzmocnionych poprzecznymi ściągami, połączonych na swych końcach z podłużnicą dachową, będąca jednocześnie elementem łączącym dach ze ścianą boczną wagonu. Krokwie wykonane są z zetowników giętych $\mathrm{z}$ blachy o grubości $3 \mathrm{~mm}$, a ściagi $\mathrm{w}$ postaci kątowników $\mathrm{z}$ blachy $2 \mathrm{~mm}$. Podłużnica dachowa wykonana jest $\mathrm{z}$ blachy $1.5 \mathrm{~mm}$. Całość pokryta jest blachą ryflowaną o grubości $1.5 \mathrm{~mm}$.

Elementem, na który zwrócono szczególną uwagę, jest blacha poszyciowa. Zamodelowano ją tak, aby można było jej przypisać własności zarówno jako elementowi stalowemu jednorodnemu, jak i elementowi o strukturze porowatej. Szczegóły przedstawiono poniżej.

Własności materiałowe, zmienne na grubości powłoki w przekroju poprzecznym, zostały zdyskretyzowane za pomocą 41 warstw o stałej grubości $t_{i}$ oraz o stałych wskaźnikach mechanicznych. Poszczególne warstwy miały stałe materiałowe obliczone wg zależności przedstawionych w pracy [3]:

$$
\begin{aligned}
& E(z)=E_{1}\left[1-e_{0} \cos (\pi \zeta)\right] \\
& G(z)=G_{1}\left[1-e_{0} \cos (\pi \zeta)\right]
\end{aligned}
$$

gdzie:

$$
e_{0}=1-\frac{E_{0}}{E_{1}}=1-\frac{G_{0}}{G_{1}}-\text { współczynnik }
$$


porowatości powłoki, $G_{j}=\frac{E_{j}}{2(1+v)}, j=0,1$,

$E_{0}, G_{0}, E_{1}, G_{1}$ - moduły sprężystości dla $\zeta=0$

i $\zeta= \pm \frac{1}{2}$,

$\zeta=\frac{z}{t}-$ bezwymiarowa współrzędna,

$v$ - liczba Poissona.

Liczbę Poissona przyjęto jednakową dla wszystkich warstw i była ona równa 0,3 . Całkowita grubość porowatej powłoki $t_{\mathrm{p}} \mathrm{w}$ badaniach MES-em (Metoda Elementów Skończonych) wynosi:

$$
t_{p}=\sum_{i}^{N} t_{i}
$$

gdzie:

$$
\begin{aligned}
& N \text { - suma wszystkich warstw }(\mathrm{N}=41), \\
& \mathrm{i} \text { - numer warstwy. }
\end{aligned}
$$

Współrzędną $\mathrm{z}_{\mathrm{i}}$, dla której zdefiniowano stałe materiałowe dla i-tej warstwy, obliczono na podstawie wzoru:

$$
z_{i}=\frac{i-1}{2} t_{i}
$$

Zagadnienie ugięć panela walcowego o strukturze porowatej było przedmiotem badań [4] i w pracy tej przedstawiono wyniki badań dla modelu analitycznego i dyskretnego.

Schemat porowatej powłoki i sposób dyskretyzacji stałych materiałowych przedstawiono na rys.1.
Model dyskretny fragmentu dachu przedstawiono na rys.2. Badania wykonano MES-em za pomoca programu ANSYS. W modelu obliczeniowym uwzględniono symetrię płaszczyznową oraz cykliczną, wystęującą w rzeczywistej konstrukcji dachu wagonu. W miejscu podparcia modelu na ścianie bocznej wagonu umożliwiono przesunięcie $\mathrm{w}$ kierunku poprzecznym. Krawędzie krokwi kończące model utwierdzono na przemieszczenie w kierunku wzdłużnym i obrót względem osi poprzecznej. Obciążenie śniegiem przyłożono na górnej części dachu do wysokości położenia ściagu.

Do obliczeń zastosowano element powłokowy wielowarstwowy SHELL99 oraz element belkowy BEAM188 o przekrojach poprzecznych odpowiadających kształtownikom usztywniającym poszycie dachu wagonu. Model obliczeniowy zawierał 12981 elementów, w tym 11900 elementów typu SHELL oraz 1081 elementów typu BEAM. Cały model posiadał 72470 aktywnych stopni swobody.

Wyniki badań wykonano dla następujących danych przyjętych dla powłoki walcowej: $\mathrm{E}_{1}=0,205 \mathrm{GPa}$; $\nu=0,3 ; \mathrm{e}_{0}=0,0 ; 0,45 ; 0,90 ; 0,99$.

\section{Omówienie wyników analizy}

$\mathrm{Na}$ rys.3 i 4 przedstawiono $\mathrm{w}$ celach orientacyjnych przykładowy rozkład przemieszczeń poziomych i pionowych powstający w modelu dachu pod obciążeniem śniegiem. Szczegółowe wyniki zestawiono w sposób tabelaryczny.

W tabeli 1 zamieszczono wyniki obliczeń numerycznych maksymalnego bezwymiarowego ugięcia

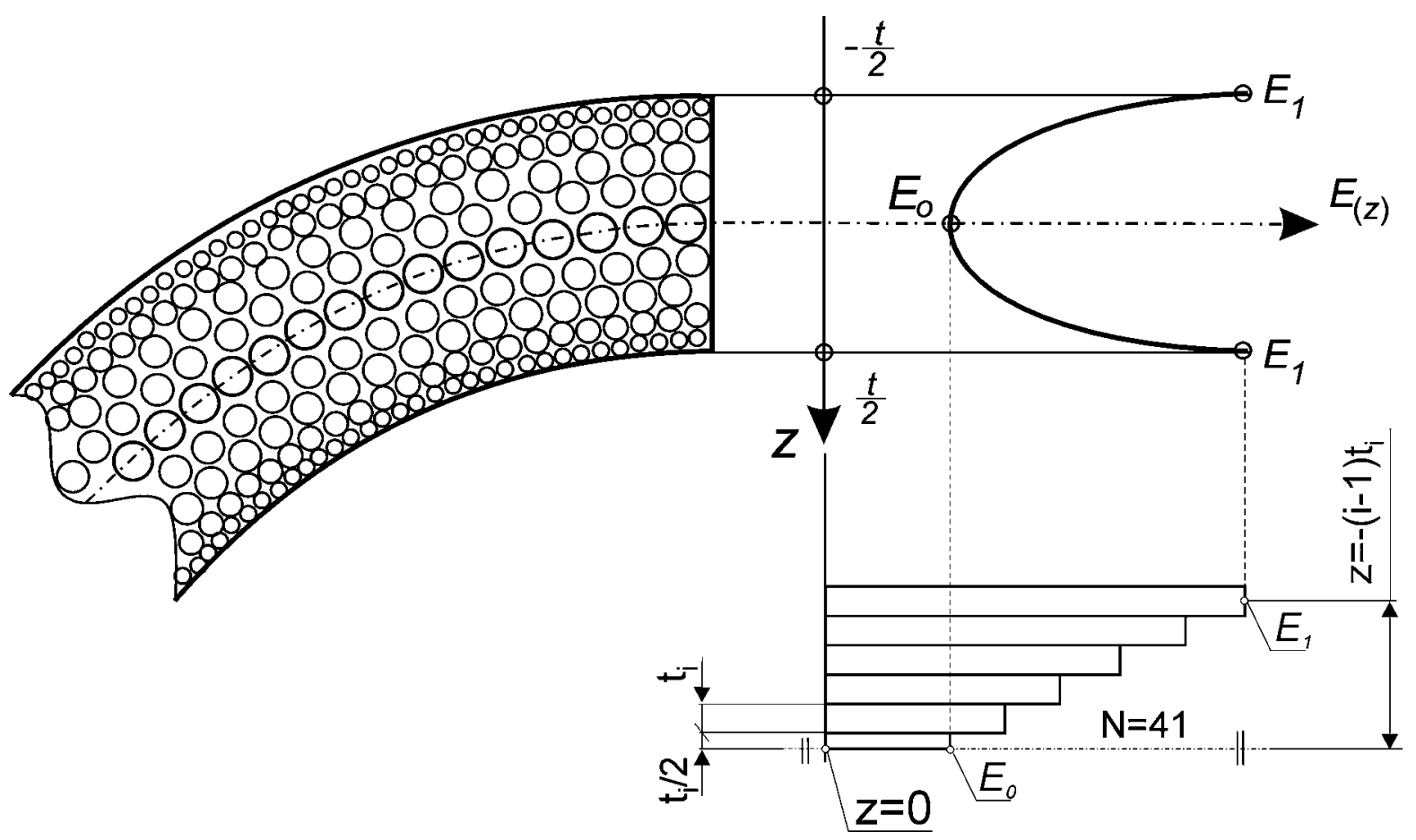

Rys.1 Schemat porowatej powłoki i aproksymacja prostokątna stałych materiałowych 


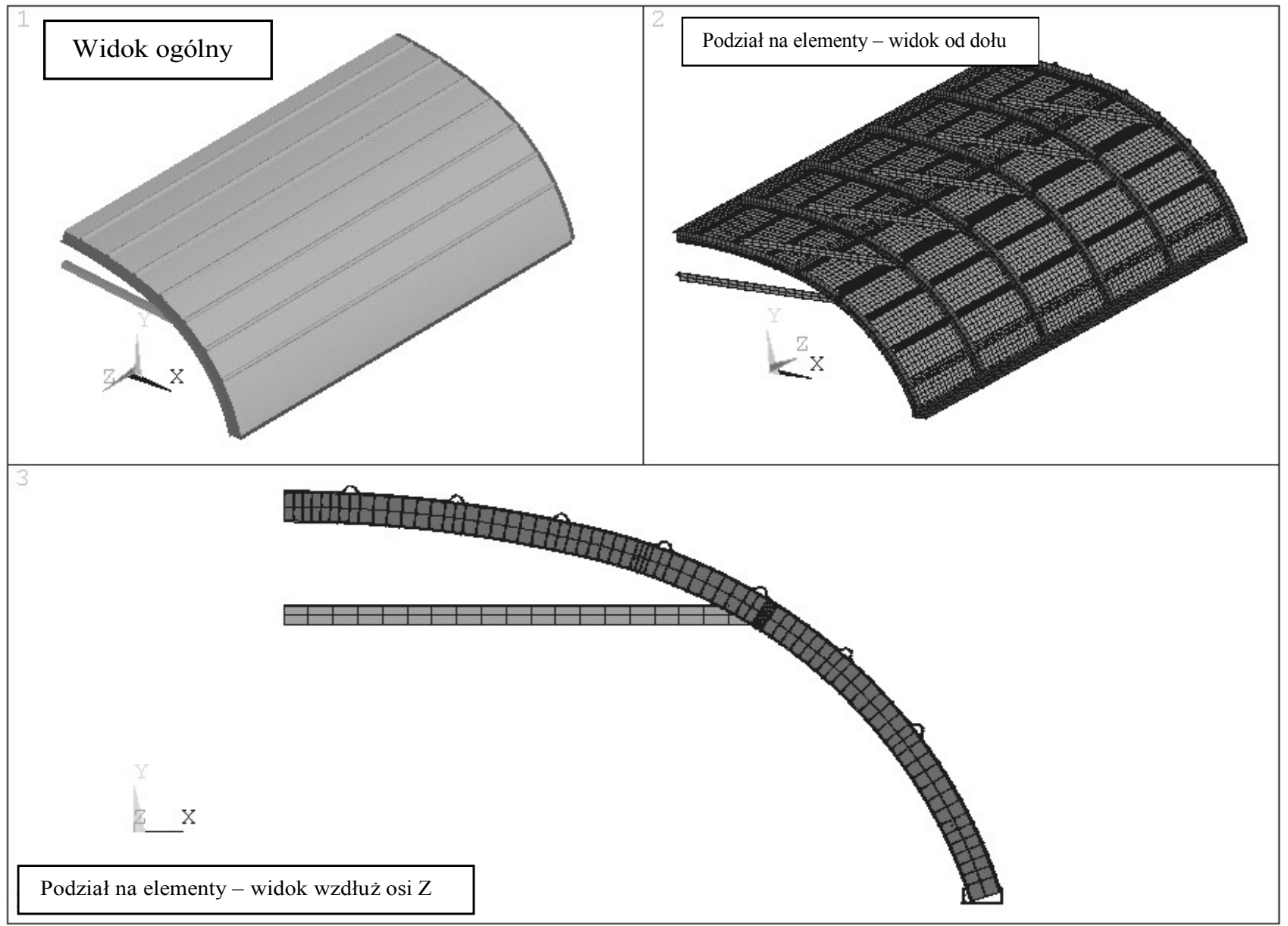

Rys.2 Model dyskretny fragmentu dachu wagonu

poziomego $u_{x} / t$, pionowego $u_{y} / t$, stosunku maksymalnych naprężeń zredukowanych dla powłoki klasycznej i o strukturze porowatej $\sigma_{\text {red }} / \sigma_{\text {redp }}$ oraz stosunku ich mas $m / m_{p}$ ( $m_{p}$-masa powłoki o strukturze porowatej).

Konstrukcja dachu o strukturze porowatej jest wrażliwa na ugięcia poziome i w porównaniu $\mathrm{z}$ klasyczną konstrukcją jej maksymalne ugięcie poziome jest około 1,42 razy większe niż w przypadku dachu klasycznego, dla współczynnika porowatości $\mathrm{e}_{0}=0,45$. W przypadku większej porowatości struktury np. $\mathrm{e}_{0}=0,99$ iloraz ten jest większy i dochodzi do wartości 2,80.

Podobnie jest w przypadku ugięć pionowych. Dla współczynnika porowatości $\mathrm{e}_{0}=0,45$ maksymalne ugięcie pionowe jest 1,34 razy większe niż w przypadku powłoki o strukturze jednorodnej i 2,39 razy większe dla $\mathrm{e}_{0}=0,99$.

Istotne $\mathrm{z}$ wytrzymałościowego punktu widzenia są naprężenia zredukowane. $Z$ tabeli 1 wynika, że dla całej rodziny powłok porowatych maksymalne naprężenia zredukowane $\sigma_{\text {redp }}$ są mniejsze niż w przypadku konstrukcji klasycznej (maksymalnie do 2,3\% dla porowatości $\mathrm{e}_{0}=0,99$ ).
Bezwymiarowe ugięcie poziome, pionowe oraz stosunek naprężeń zredukowanych i mas $\left(t=t_{p}\right)$

Tabela 1

\begin{tabular}{|c|c|c|c|c|c|}
\hline L.p. & $\begin{array}{c}\text { Wspótczynnik } \\
\text { porowatości }\end{array}$ & $u_{x} / t$ & $u_{y} / t$ & $\sigma_{\text {red }} / \sigma_{\text {redp }}$ & $m / m_{p}$ \\
\hline 1 & $e_{0}=0,0$ & 0,109 & 0,757 & 1,0 & 1,0 \\
\hline 2 & $e_{0}=0,45$ & 0,155 & 1,011 & 1,008 & 1,401 \\
\hline 3 & $e_{0}=0,90$ & 0,263 & 1,589 & 1,020 & 2,342 \\
\hline 4 & $e_{0}=0.99$ & 0,305 & 1,808 & 1,023 & 2,705 \\
\hline
\end{tabular}

Stosunek grubości powłok oraz ich mas przy jednakowym ugięciu pionowym

Tabela 2

\begin{tabular}{|c|c|c|c|c|c|}
\hline L.p. & $\begin{array}{c}\text { Wspótczynnik } \\
\text { porowatości }\end{array}$ & $t / t_{p}$ & $t_{p} / t$ & $m / m_{p}$ & $m_{p} / m$ \\
\hline 1 & $e_{0}=0,0$ & 1,0 & 1,0 & 1,0 & 1,0 \\
\hline 2 & $e_{0}=0,45$ & 0,848 & 1,179 & 1,191 & 0,840 \\
\hline 3 & $e_{0}=0,90$ & 0,658 & 1,520 & 1,539 & 0,650 \\
\hline 4 & $e_{0}=0.99$ & 0,613 & 1,631 & 1,667 & 0,599 \\
\hline
\end{tabular}


W tabeli 2 przedstawiono wyniki obliczeń numerycznych stosunków grubości $t$ i $t_{p}$ ( $t_{p}$-grubość powłoki o strukturze porowatej) oraz mas $m$ i $m_{p}$ dla rodziny powłok o strukturze porowatej o różnych współczynnikach porowatości oraz dla konstrukcji klasycznej. Badania przeprowadzono przy założeniu, że maksymalne ugięcie pionowe dachu ze struktura porowatą jest równe ugięciu maksymalnemu konstrukcji z powłoką o strukturze jednorodnej $(\mathrm{t}=1,5 \mathrm{~mm})$. Porównanie grubości powłok oraz ich mas daje wyniki, interesujące $\mathrm{z}$ poznawczego punktu widzenia.

Wraz ze wzrostem współczynnika porowatości $\mathrm{e}_{0}$ grubość powłoki porowatej $\mathrm{w}$ stosunku do grubości powłoki klasycznej rośnie (maksymalnie 1,631 razy dla $\mathrm{e}_{0}=0,99$ ), a masa powłoki porowatej maleje (do około $60 \%$ masy powłoki klasycznej dla $\mathrm{e}_{0}=0,99$ ). Daje to wymierne korzyści wynikające $\mathrm{z}$ masy całkowitej wagonu.

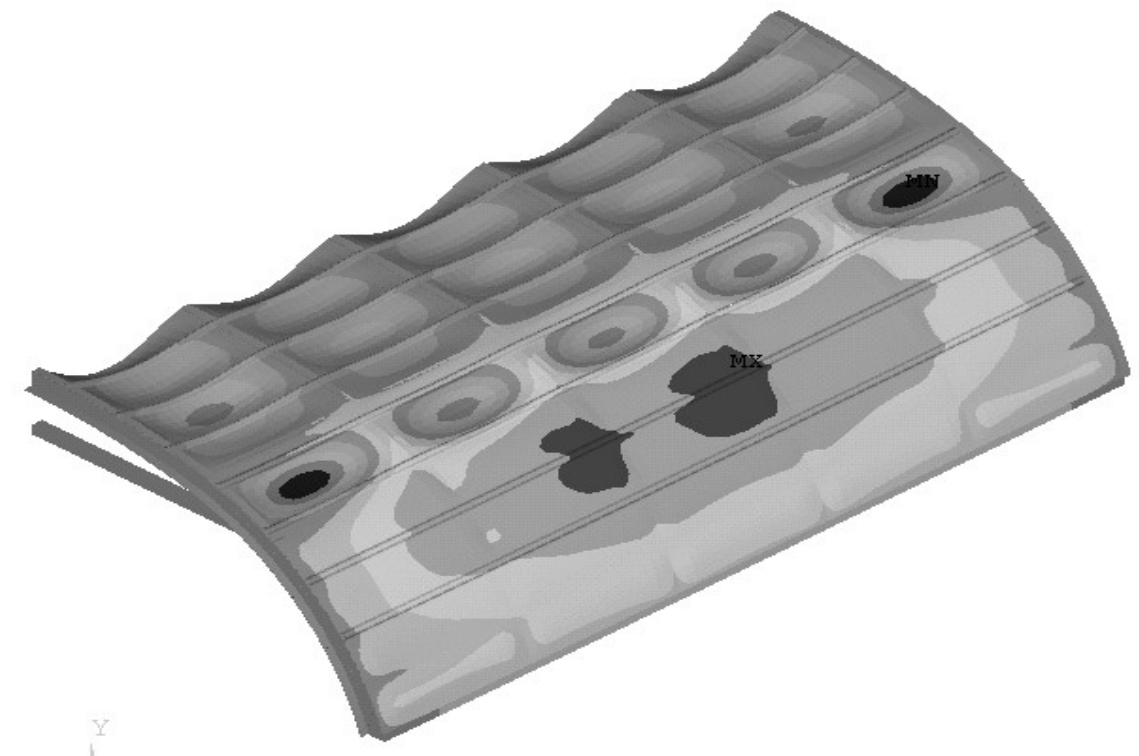

Rys.3 Rozkład przemieszczeń UX [mm] w kierunku poziomym

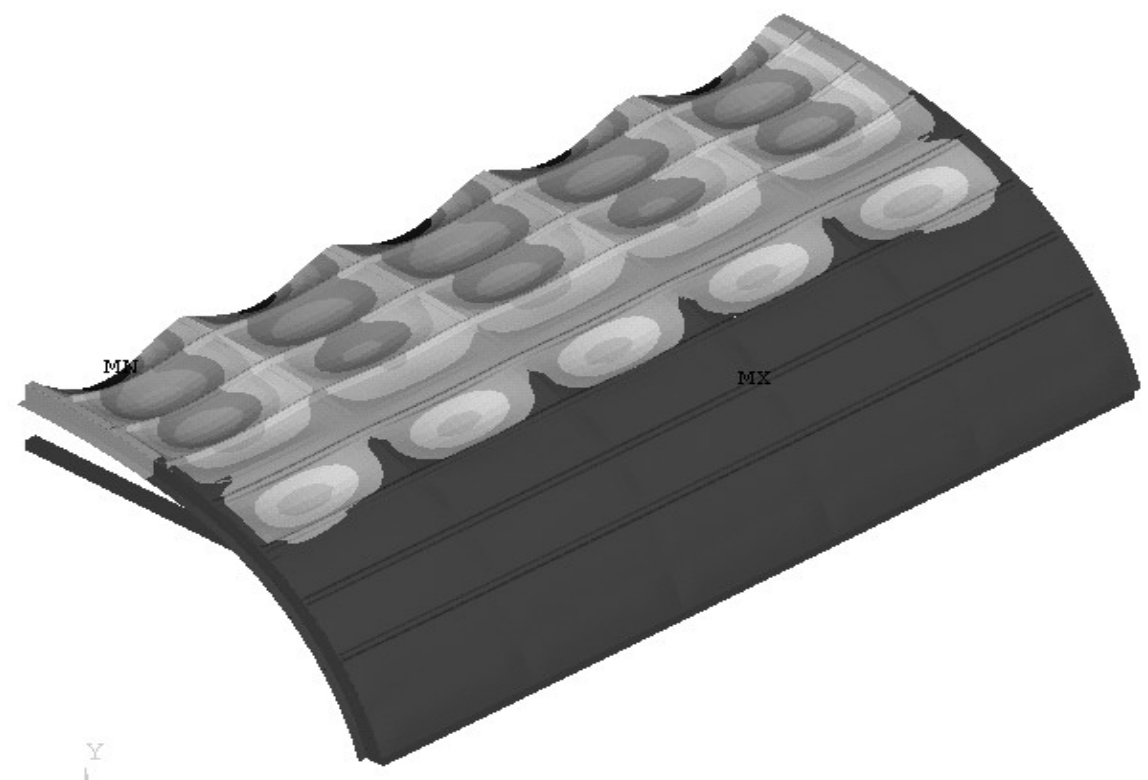

Rys.4 Rozkład przemieszczeń UY [mm] w kierunku pionowym
ANSYS 5.7

JAN 242006

$22: 57: 28$

NODAL SOLUTION

$\operatorname{STE} P=1$

SUB $=1$

TIME $=1$

UX

RSYS $=0$

(AVG)

PowerGraphics

EFACET $=1$

AVRES $=$ Mat

$\mathrm{DMX}=1.135$

SMN $=-.163207$

SMX $=.147465$

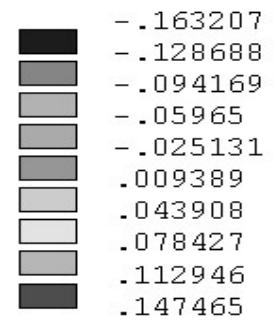

ANSYS 5.7

JAN $24 \quad 2006$

$22: 57: 39$

NODAL SOLUTION

STEP $=1$

SUB $=1$

TIME $=1$

UY

(AVG)

RSYS $=0$

PowerGraphics

EFACET $=1$

AVRES $=$ Mat

$\mathrm{DMX}=1.135$

SMN $=-1.135$

SMX $=.075401$

$-1.135$

$-1.001$

$-.866349$

$-.731813$

$-.597278$

$-.462742$

$-.328206$

$-.19367$

$-.059134$

.075401 


\section{Wnioski}

Z uzyskanych rezultatów wynika, że zastosowanie materiałów o strukturze porowatej na elementy powierzchniowe poszycia dachów pojazdów szynowych jest możliwe. Wymusza to zastosowanie nieco grubszej powłoki oraz pewnych zmian konstrukcyjnych szkieletu dachu (m.in. w celu spełnienia wymagań skrajni kinematycznej), ale pojawia się znaczący zysk na masie (mogący dochodzić nawet do $60 \%$ ) co ma niebagatelne znaczenie zwłaszcza w przypadku długich wagonów jakimi są wagony pasażerskie. Zaproponowane rozwiązanie modelowe można by $\mathrm{z}$ powodzeniem zastosować $\mathrm{w}$ innych obszarach konstrukcji pojazdów szynowych. W pracy nie uwzględniono zjawisk termomechanicznych. Stosowanie materiałów porowatych znacznie zwiększa izolacyjność cieplną poszycia dachu, wykluczając konieczność montowania specjalnych warstw docieplających.

\section{Literatura}

[1] Mielniczuk J., Malinowski M.: Modele materiatów porowatych $w$ projektowaniu konstrukcyjnych elementów powierzchniowych, Pojazdy Szynowe, $3 / 2005$.

[2] Kuligowski P.: Analiza odkształceń konstrukcji nośnej dachu wagonu pasażerskiego. Opracowanie OR-9010 (niepublikowane), Instytut Pojazdów Szynowych ,TABOR” Poznań, 2005.

[3] Magnucki K., Stasiewicz P.: Elastic bending of an isotropic porous beam, Int. Journal of Applied Mechanics and Engineering, 9(2), 2004.

[4] Malinowski M., Magnucki K.: Deflection of an isotropic porous cylindrical panel, Shell structures: theory and applications: proceedings of the 8th SSTA Conference, ed. W. Pietraszkiewicz, C. Szymczak, London: Taylor \& Francis, 2005. 